\title{
A multifunctional thermophilic glycoside hydrolase from Caldicellulosiruptor owensensis with potential applications in production of biofuels and biochemicals
}

\author{
Xiaowei Peng, Hong Su, Shuofu Mi and Yejun Han ${ }^{*}$
}

\begin{abstract}
Background: Thermophilic enzymes have attracted much attention for their advantages of high reaction velocity, exceptional thermostability, and decreased risk of contamination. Exploring efficient thermophilic glycoside hydrolases will accelerate the industrialization of biofuels and biochemicals.

Results: A multifunctional glycoside hydrolase $(\mathrm{GH}) \mathrm{CoGH1A}$, belonging to $\mathrm{GH} 1$ family with high activities of $\beta$-Dglucosidase, exoglucanase, $\beta$-D-xylosidase, $\beta$-D-galactosidase, and transgalactosylation, was cloned and expressed from the extremely thermophilic bacterium Caldicellulosiruptor owensensis. The enzyme exerts excellent thermostability by retaining $100 \%$ activity after 12 -h incubation at $75^{\circ} \mathrm{C}$. The catalytic coefficients $\left(k_{\text {cat }} / K_{m}\right)$ of the enzyme against $p N P-\beta$-D-galactopyranoside, $p N P$ - $\beta$-D-glucopyranoside, $p N P-\beta$-D-cellobioside, $p N P-\beta$-D-xylopyranoside, and cellobiose were, respectively, 7450.0, 2467.5, 1085.4, 90.9, and $137.3 \mathrm{mM}^{-1} \mathrm{~s}^{-1}$. When CoGH1A was supplemented at the dosage of $20 \mathrm{U}_{\text {cellobiose }} \mathrm{g}^{-1}$ biomass for hydrolysis of the pretreated corn stover, comparing with the control, the glucose and xylose yields were, respectively, increased 37.9 and $42.1 \%$, indicating that the enzyme contributed not only for glucose but also for xylose release. The efficiencies of lactose decomposition and synthesis of galactooligosaccharides (GalOS) by CoGH1A were investigated at low $\left(40 \mathrm{~g} \mathrm{~L}^{-1}\right)$ and high $\left(500 \mathrm{~g} \mathrm{~L}^{-1}\right)$ initial lactose concentrations. At low lactose concentration, the time for decomposition of $83 \%$ lactose was $10 \mathrm{~min}$, which is much shorter than the reported 2-10 h for reaching such a decomposition rate. At high lactose concentration, after 50-min catalysis, the GalOS concentration reached $221 \mathrm{~g} \mathrm{~L}^{-1}$ with a productivity of $265.2 \mathrm{~g} \mathrm{~L}^{-1} \mathrm{~h}^{-1}$. This productivity is at least 12 -fold higher than those reported in literature.
\end{abstract}

Conclusions: The multifunctional glycoside hydrolase CoGH1A has high capabilities in saccharification of lignocellulosic biomass, decomposition of lactose, and synthesis of galactooligosaccharides. It is a promising enzyme to be used for bioconversion of carbohydrates in industrial scale. In addition, the results of this study indicate that the extremely thermophilic bacteria are potential resources for screening highly efficient glycoside hydrolases for the production of biofuels and biochemicals.

Keywords: $\beta$-D-glucosidase, Exoglucanase, $\beta$-D-xylosidase, $\beta$-D-galactosidase, Transglycosylation, Lignocellulose, Galactooligosaccharides, Caldicellulosiruptor

*Correspondence: yjhan@ipe.ac.cn

National Key Laboratory of Biochemical Engineering, Institute of Process

Engineering, Chinese Academy of Sciences, Beijing, China 


\section{Background}

Glycoside hydrolases (GHs) are enzymes hydrolyzing the glycosidic bond between carbohydrates or between a carbohydrate and a non-carbohydrate moiety [1]. GHs are widely applied in biological and chemical industries. Among them, cellulases (including endoglucanase, exoglucanase, and $\beta$-glucosidase) are of great interest for application in biomass degradation for biofuel and biochemical production [2]. In addition, some GHs have the capability of transglycosylation and are used for synthesis of oligosaccharides and glycosides, such as galactooligosaccharides (GalOS) (synthesized by $\beta$-galactosidase) [3] and octyl glucoside (synthesized by $\beta$-glucosidase) [4]. Production of efficient GHs is urgently required to improve the economical possibility for the related industrial products. Especially, efficient cellulase production has developed into a significant bottleneck for the biofuel industry [1]. Research efforts have recently focused on extremely thermophilic microorganisms for exploring novel cellulases and other GHs to improve the current situation [5-7], due to the advantages of these thermophilic enzymes, such as higher reaction velocity, excellent thermostability, and decreased risk of contamination [8]. Many thermophilic GHs, such as $\beta$-D-glucosidase $[9,10]$, bifunctional cellulolytic enzyme (endo- and exoglucanases) [11], $\beta$-D-xylosidase [12], and $\beta$-D-galactosidase $[3,13]$, have been cloned, heterologously expressed, and biochemically characterized for the purpose of uncovering the catalytic mechanism and evaluating the possibility of industrial applications. Among them, the genus Caldicellulosiruptor has recently attracted high interest for it can produce a diverse set of glycoside hydrolases (GHs) for deconstruction of lignocellulosic biomass $[7,14,15]$. The open Caldicellulosiruptor pangenome encoded 106 glycoside hydrolases (GHs) from $43 \mathrm{GH}$ families [7]. Our previous work [16] found that the extremely thermophilic bacterium Caldicellulosiruptor owensensis had comprehensive hemicellulase and cellulase system with potential application for bioconversion of lignocellulosic biomass. Moreover, the catalytic mechanism of some enzymes from Caldicellulosiruptor differs from the general GHs. For example, the cellulase CelA produced from Caldicellulosiruptor bescii could hydrolyze the microcrystalline cellulose not only from the surface as common cellulases done but also by excavating extensive cavities into the surface of the substrate [17]. The information about their genetic, biochemical, and biophysical characteristics suggests that there exist more efficient GHs to be explored in the extremely thermophilic microorganisms Caldicellulosiruptor.

In the present work, a multifunctional glycoside hydrolase $(\mathrm{GH})$ was cloned and expressed from $C$. owensensis. The characteristics of the enzyme and its potential applications in saccharification of lignocellulosic biomass and synthesis of galactooligosaccharides (GalOS) were evaluated.

\section{Results and discussion Cloning and expression of $\mathrm{CoGH} 1 \mathrm{~A}$}

The gene Calow_0296 consists of a 1359 bp fragment encoding 452 amino acids, which belongs to glycoside hydrolase family 1 (GH1) and was named CoGH1A. The predicted molecular weight of CoGH1A was $53.2 \mathrm{kDa}$. The SDS-PAGE analysis agreed with the predicted sizes (Fig. 1b). The quaternary structure of purified CoGH1A was analyzed through gel filtration chromatography coupled with SDS-PAGE. The results are shown in Fig. 1. The molecular mass (MW) of CoGH1A at peak $1(160.4 \mathrm{kDa})$ was almost three times that at peak 2 (53.3 kDa) (Fig. 1a). However, fractions collected from two peaks showed the same band in SDS-PAGE (Fig. 1b). This suggests that $\mathrm{CoGH} 1 \mathrm{~A}$ exists as monomer and homotrimer in buffer. Two thermostable $\beta$-glucosidases, one belonging to GH1 from the Termite Nasutitermes takasagoensis [18] and the other belonging to GH3 from Thermoascus aurantiacus [19], were also homotrimers but not monomers in their native form. It is interesting that both monomer and homotrimer of CoGH1A exist in native form. It seems that monomer and homotrimer collectively function on the substrate.

\section{Optimum temperature, $\mathrm{pH}$ and thermostability of CoGH1 A}

The effects of temperature and $\mathrm{pH}$ on the activity of CoGH1A using $p$ NP- $\beta$-D-galactopyranoside as the substrate are shown in Fig. 2a, b. It shows that the optimum

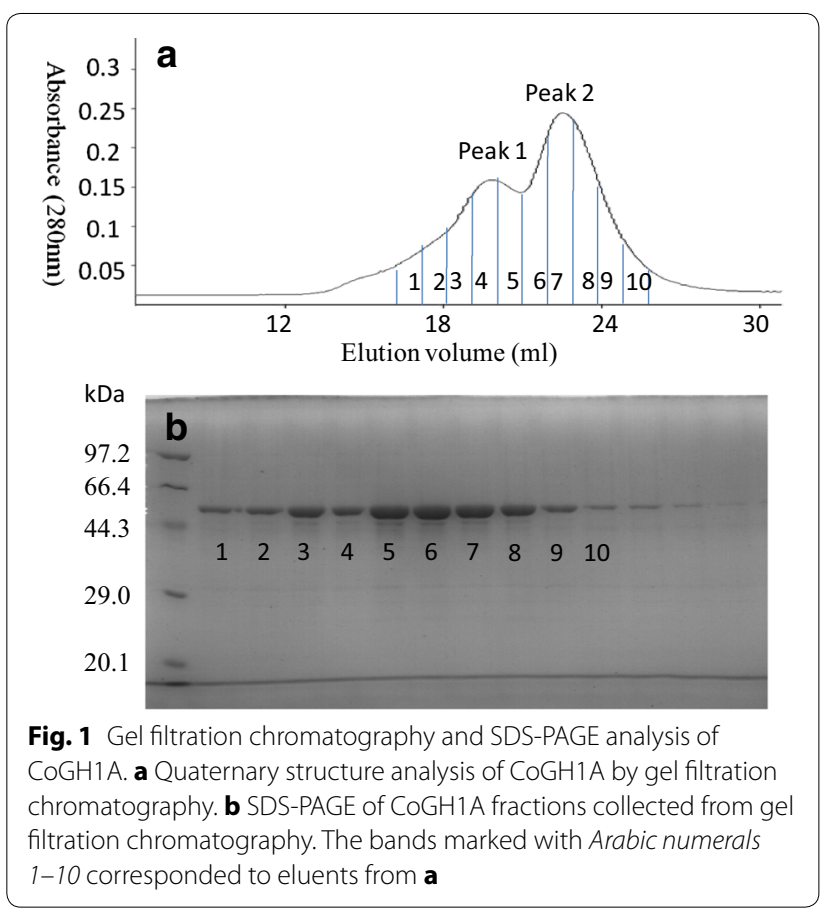



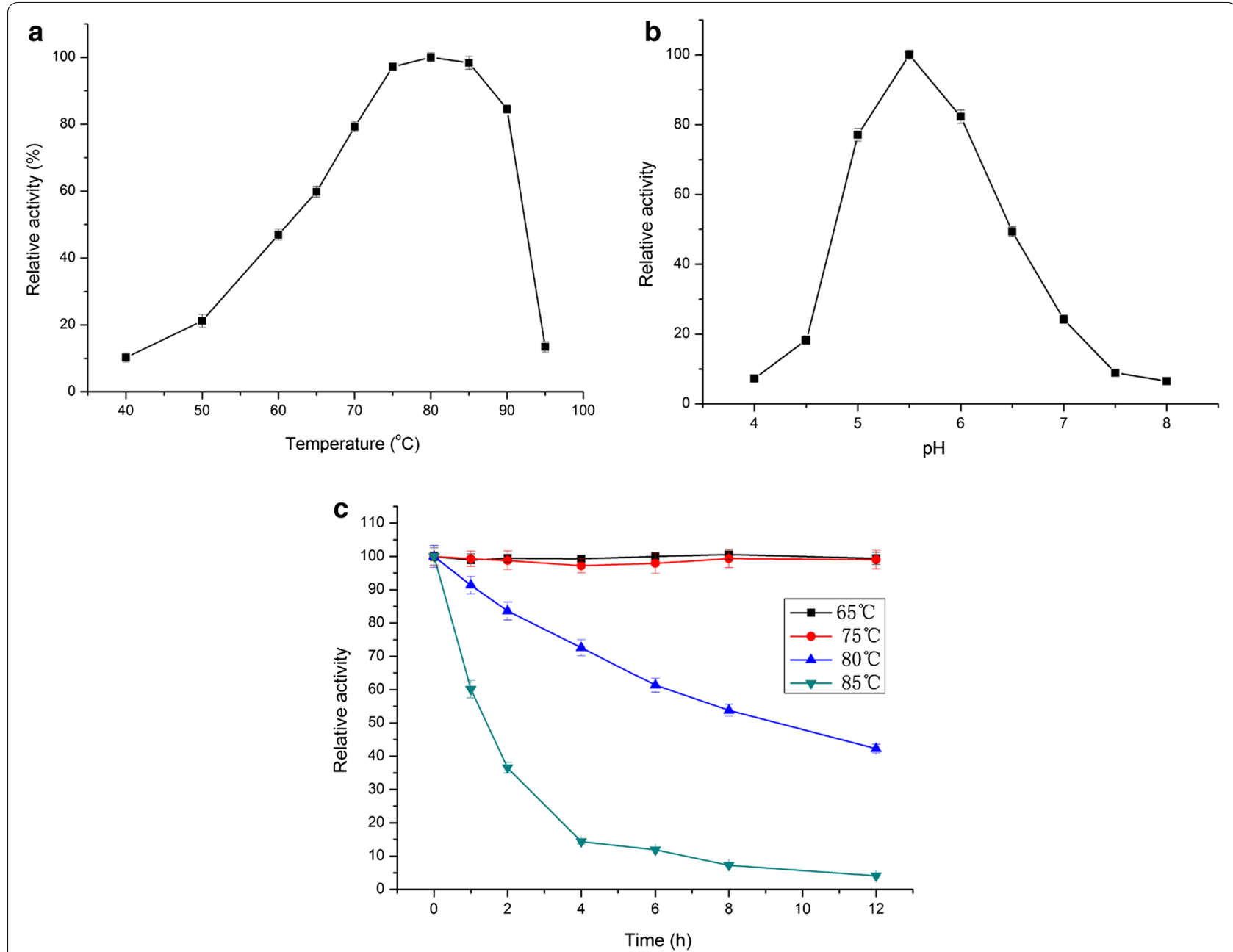

Fig. 2 Effect of temperature (a) and pH (b) on activity and thermostability (c) of CoGH1A. Values are averages counted from three independent measures; error bars represent standard deviation

temperature of CoGH1A was from 75 to $85{ }^{\circ} \mathrm{C}$, which is in accordance with the optimum temperature for $C$. owensensis growth at $75{ }^{\circ} \mathrm{C}[20]$. At 70 and $90{ }^{\circ} \mathrm{C}$, the activities of CoGH1A were more than $80 \%$ of the maximum, while below $60{ }^{\circ} \mathrm{C}$ the enzyme activity decreased to less than $50 \%$ of the maximum. This indicates that CoGH1A is an extremely thermophilic enzyme and has broad temperature adaptability. The optimum $\mathrm{pH}$ of CoGH1A was 5.5. At the $\mathrm{pH}$ of 5.0 and 6.0, the activities of CoGH1A were about $80 \%$ of the maximum. At the $\mathrm{pH}$ of 4.5 and 7.0, the activities of CoGH1A were deceased to about $20 \%$ of the maximum. It is better to control the $\mathrm{pH}$ from 5.0 to 6.0 for application of CoGH1A. This is a common $\mathrm{pH}$ for most of the glycoside hydrolases.

The thermostability of CoGH1A is shown in Fig. 2c. After $12 \mathrm{~h}$ of incubation in $\mathrm{pH} 5.5$ citrate buffer at 65 and $75{ }^{\circ} \mathrm{C}$, the activities of the enzyme remained the same as that of the initial. These results show that CoGH1A exhibits excellent thermostability at the temperatures below $75{ }^{\circ} \mathrm{C}$. The half-lives of CoGH1A were about 11 and $1.5 \mathrm{~h}$ when cultivated at 80 and $85{ }^{\circ} \mathrm{C}$, respectively. The half-lives of the $\beta$-glucosidase CbBgl1A from $C$. bescii [9] at 80 and $85^{\circ} \mathrm{C}$ were 20 and $8 \mathrm{~min}$, respectively. The half-lives of the $\beta$-galactosidase from $C$. saccharolyticus [21] at 75 and $80{ }^{\circ} \mathrm{C}$ were 17 and $2 \mathrm{~h}$, respectively. This indicates that among the enzymes from Caldicellulosiruptor species CoGH1A is a robust candidate for industrial application.

\section{Effect of ions on the activity of CoGH1A}

The effect of cations on the activity of CoGH1A was detected at pH 5.5 and $75{ }^{\circ} \mathrm{C}$ (Table 1). On the whole, at the concentrations of both 5 and $10 \mathrm{mM}$, the effects of cations on the activity of CoGH1A were not significant. 
Table 1 Effect of cations on the activity of CoGH1A

\begin{tabular}{lcc}
\hline Cations & \multicolumn{2}{c}{ Relative activity \% } \\
\cline { 2 - 3 } & $\mathbf{5} \mathbf{~} \mathbf{M}$ & $\mathbf{1 0} \mathbf{~} \mathbf{M}$ \\
\hline Control & 100 & 100 \\
$\mathrm{Fe}^{3+}$ & 92 & 83 \\
$\mathrm{Zn}^{2+}$ & 87 & 82 \\
$\mathrm{Ni}^{2+}$ & 102 & 119 \\
$\mathrm{Mn}^{2+}$ & 104 & 135 \\
$\mathrm{Co}^{2+}$ & 95 & 75 \\
$\mathrm{Mg}^{2+}$ & 76 & 80 \\
$\mathrm{Cu}^{2+}$ & 87 & 71 \\
$\mathrm{~K}^{+}$ & 114 & 105 \\
$\mathrm{Na}^{+}$ & 96 & 82 \\
$\mathrm{NH}_{4}{ }^{+}$ & 82 & 75 \\
\hline
\end{tabular}

The experiment was carried out at $75^{\circ} \mathrm{C}$ and $\mathrm{pH}$ 5.5. The $p N P G a l$ with the concentration of $1 \mathrm{mM}$ was used as the substrate

$\mathrm{Mn}^{2+}$ and $\mathrm{Ni}^{2+}$ activated the enzyme activity by 135 and $119 \%$, respectively, at the concentration of $10 \mathrm{mM} . \mathrm{K}^{+}$ activated the enzyme activity by 114 and $105 \%$, respectively, at the concentrations of 5 and $10 \mathrm{mM}$. The other cations, such as $\mathrm{Fe}^{3+}, \mathrm{Zn}^{2+}, \mathrm{Co}^{2+}, \mathrm{Mg}^{2+}, \mathrm{Cu}^{2+}, \mathrm{Na}^{+}$, and $\mathrm{NH}_{4}{ }^{+}$, slightly inhibited the enzyme activity by 71-96\%. These results indicate that $\mathrm{CoGH} 1 \mathrm{~A}$ has resistance to cations and additional cation is not necessary for activating the enzyme. The effects of cation on CoGH1A were similar to those on some other glycoside hydrolases from Caldicellulosiruptor species, such as the xylanase from $C$. kronotskyensis [22] and the xylanase and xylosidase from C. owensensis [12]. They were very different from the $\beta$-galactosidase produced by Lactobacillus delbrueckii [23]. The $\mathrm{K}^{+}$and $\mathrm{Na}^{+}$activated that $\beta$-galactosidase with the activities increased almost 5- and 12-fold, respectively, at the ion concentration of $50 \mathrm{mM}$, while $\mathrm{Zn}^{2+}$ significantly inhibited the activity of that $\beta$-galactosidase with the activity decreased to almost zero at the $\mathrm{Zn}^{2+}$ concentration of $10 \mathrm{mM}$.

\section{Specific activities and kinetic parameters of CoGH1A on different substrates}

The activities of CoGH1A on various substrates were tested at $75{ }^{\circ} \mathrm{C}$ and $\mathrm{pH}$ 5.5. The results (Table 2) show that the enzyme exhibited broad substrate specificity. The highest specific activity was $3215 \mathrm{U} \mathrm{mg}^{-1}$ with $p \mathrm{NP}-\beta-\mathrm{D}-$ galactopyranoside ( $p$ NPGal) as the substrate, followed by $1621,603,280,140$, and $130 \mathrm{U} \mathrm{mg}^{-1}$ with $p \mathrm{NP}-\beta$ D-glucopyranoside ( $p$ NPGlu $), \quad p$ NP- $\beta$-D-cellobioside $(p \mathrm{NPC})$, lactose, $p \mathrm{NP}-\beta$-D-xylopyranoside ( $p \mathrm{NPX})$, and cellobiose, respectively, as substrates. Also, the enzyme displayed activities on soluble polysaccharides such as synanthrin $\left(2.4 \mathrm{U} \mathrm{mg}^{-1}\right)$ and locust bean gum
Table 2 Specific activities of CoGH1A on different substrates

\begin{tabular}{ll}
\hline Substrate & Specific activity $\left.\mathbf{(} \mathbf{~ m g}^{\mathbf{- 1}}\right)$ \\
\hline$p N P G a l^{a}$ & $3215 \pm 6.2$ \\
$p^{a} P G l^{a}$ & $1621 \pm 15.6$ \\
$p N P C^{a}$ & $603 \pm 11.4$ \\
$p N P X^{a}$ & $140 \pm 5.4$ \\
Cellobiose $^{a}$ & $130 \pm 3.6$ \\
Lactose $^{a}$ & $280 \pm 4.2$ \\
Locust bean gum $^{b}$ & $2.4 \pm 0.2$ \\
Synanthrin $^{b}$ & $1.2 \pm 0.1$ \\
Cotton $^{b}$ & $<0.1$ \\
Filter paper $^{b}$ & $<0.1$ \\
pNPAr $^{\mathrm{a}}$ & $\mathrm{ND}$ \\
CMC $^{b}$ & $\mathrm{ND}$ \\
\hline
\end{tabular}

ND not detected

a Initial concentration was $1 \mathrm{mM}$

b Initial concentration was $1 \%(\mathrm{~W} / \mathrm{V})$

$\left(1.2 \mathrm{U} \mathrm{mg}^{-1}\right)$. The enzyme even hydrolyzed insoluble substrates with slight activities on cotton $\left(<0.1 \mathrm{U} \mathrm{mg}^{-1}\right)$ and filter paper $\left(<0.1 \mathrm{U} \mathrm{mg}^{-1}\right)$. However, it exhibited no activity against carboxymethyl cellulose (CMC) and $p N P-\alpha-L_{-}$ arabinofuranoside ( $p$ NPAr).

The kinetic parameters of CoGH1A were determined on several preferred substrates at $75{ }^{\circ} \mathrm{C}$ and $\mathrm{pH}$ 5.5 (Table 3 ). The $K_{\mathrm{m}}$ values against $p$ NPGal, $p$ NPGlu, $p$ NPC, pNPX, and cellobiose were 0.61, 1.52, 0.87, 7.18, and $15.65 \mathrm{mM}$, respectively. The catalytic coefficients $\left(k_{\text {cat }} / K_{\mathrm{m}}\right)$ on the five substrates were, respectively, 7450.0, $2467.5,1085.4,90.9$, and $137.3 \mathrm{mM}^{-1} \mathrm{~s}^{-1}$.

A complete cellulase system consists of at least three related enzymes: endoglucanases (EC 3.2.1.4), exoglucanases (or cellobiohydrolase) (EC 3.2.1.91), and $\beta$-glucosidases (EC 3.2.2.21) [24]. They cooperate in releasing glucose. Endoglucanases (EC 3.2.1.4) randomly hydrolyze internal glycosidic bonds to decrease the length of the cellulose chain and multiply polymer ends. Exoglucanases (EC 3.2.1.91) split-off cellobiose or glucose from cellulose termini and $\beta$-glucosidases (EC 3.2.2.21) hydrolyze cellobiose and oligomers to render glucose [24]. Among them, $\beta$-glucosidases are essential for efficient hydrolysis of cellulosic biomass as they relieve the inhibition of the cellobiohydrolases and endoglucanases by reducing cellobiose accumulation [25]. Commercial cellulase preparations are mainly based on mutant strains of Trichoderma reesei which have usually been characterized by a low secretion of $\beta$-glucosidase [26]. Thus, T. reesei cellulase preparations had to be supplemented with added $\beta$-glucosidase to provide the more efficient saccharification of cellulosic substrates [26, 
Table 3 Kinetic parameters of CoGH1A on different substrates

\begin{tabular}{|c|c|c|c|c|}
\hline Substrate & $K_{\mathrm{m}}(\mathrm{mM})$ & $\begin{array}{l}V_{\max }(\mu \mathrm{mol} \\
\left.\mathrm{mg}^{-1} \min ^{-1}\right)\end{array}$ & $k_{\text {cat }}\left(\mathrm{s}^{-1}\right)$ & $\begin{array}{l}k_{\mathrm{cat}} / K_{\mathrm{m}} \\
\left(\mathrm{mM}^{-1} \mathrm{~s}^{-1}\right)\end{array}$ \\
\hline pNPGal & $0.61 \pm 0.025$ & $5100 \pm 64$ & $4522 \pm 56.7$ & 7450.0 \\
\hline pNPGlu & $1.52 \pm 0.2$ & $4027 \pm 75$ & $3750.6 \pm 66.5$ & 2467.5 \\
\hline$p N P C$ & $0.87 \pm 0.12$ & $1065 \pm 38$ & $944.3 \pm 33.7$ & 1085.4 \\
\hline$p N P X$ & $7.18 \pm 1.4$ & $736 \pm 35$ & $652.6 \pm 31.0$ & 90.9 \\
\hline Cellobiose & $15.65 \pm 1.52$ & $2424 \pm 48$ & $2149 \pm 43$ & 137.3 \\
\hline
\end{tabular}

27]. Much has been devoted to finding highly efficient $\beta$-glucosidases for bioconversion of cellulosic substrates. Some of the $\beta$-glucosidases with relatively high activity are listed in Table 4. The $V_{\max }$ of CoGH1A was $4027 \pm 75$ and $2424 \pm 48 \mu \mathrm{mol} \mathrm{mg} \mathrm{min}^{-1} \mathrm{~min}^{-1}$ with $p$ PGlu and cellobiose, respectively, as substrates, which was lower than that of the $\beta$-glucosidase from Pholiota adipose with the

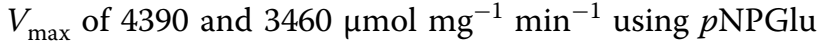
and cellobiose, respectively, as substrates [28]. However, the thermostability of CoGH1A was better than that of the $\beta$-glucosidase from Pholiota adipose. The former kept $100 \%$ activity after incubated at $75{ }^{\circ} \mathrm{C}$ for $12 \mathrm{~h}$ (Fig. 2c) and the latter kept $50 \%$ activity after incubated at $70{ }^{\circ} \mathrm{C}$ for $8.5 \mathrm{~h}$ [28]. The catalytic coefficient $\left(k_{\text {cat }} / K_{\mathrm{m}}\right)$ of the $\beta$-glucosidase from the hyperthermophilic bacterium Thermotoga petroph was $30,800 \mathrm{mM}^{-1} \mathrm{~s}^{-1}$ with $p$ NPGlu as a substrate [10]. To the best of our knowledge, this is by far the highest reported $\beta$-glucosidase activity with $p$ NPGlu as a substrate. However, the capability of this $\beta$-glucosidase for hydrolysis of cellobiose was very low, with the specific activity of only $2.3 \mathrm{U} \mathrm{mg}^{-1}$ [10]. This will limit its application in saccharification of lignocellulosic biomass. Another $\beta$-glucosidase from the same genus bacterium strain $C$. bescii was studied in detail [9]. The catalytic coefficients $\left(k_{\mathrm{cat}} / K_{\mathrm{m}}\right)$ of that $\beta$-glucosidase were 84.0 and $87.3 \mathrm{mM}^{-1} \mathrm{~s}^{-1}$ with $p$ NPGlu and cellobiose, respectively, as the substrate [9], which were much lower than those (2467.5 and $137.3 \mathrm{mM}^{-1} \mathrm{~s}^{-1}$ ) of CoGH1A. These results show that CoGH1A is a potential $\beta$-glucosidase candidate for industrial application.

Exoglucanases or cellobiohydrolases (CBHs) preferentially hydrolyze $\beta$-1, 4-glycosidic bonds from chain ends, producing cellobiose as the main product. $\mathrm{CBHs}$ have been shown to create a substrate-binding tunnel with their extended loops which surround the cellulose [29, 30]. Besides microcrystalline cellulose and cotton cellulose, the $p$ NPC was also used as a substrate for detecting the exoglucanases or cellobiohydrolase $(\mathrm{CBH})$ activity $[31,32]$. The specific activity and $V_{\max }$ of CoGH1A were,

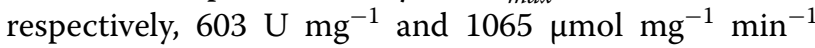
using $p$ NPC as the substrate (Tables 2,3 ), which were much higher than those for most of the reported enzymes. For example, Le et al. purified a novel cellobiohydrolase from Penicillium decumbens with a specific

Table 4 CoGH1A and some reported microbial $\beta$-glucosidases with relatively high activity

\begin{tabular}{|c|c|c|c|c|c|c|c|c|c|}
\hline Resource & GH family & Substrate & $K_{\mathrm{m}}(\mathrm{mM})$ & $\begin{array}{l}V_{\max }(\mu \mathrm{mol} \\
\left.\mathrm{mg}^{-1} \min ^{-1}\right)\end{array}$ & $k_{\text {cat }}\left(s^{-1}\right)$ & $\begin{array}{l}k_{\text {cat }} / K_{\mathrm{m}} \\
\left(\mathrm{mM}^{-1} \mathrm{~s}^{-1}\right)\end{array}$ & OT $\left({ }^{\circ} \mathrm{C}\right)$ & OP & References \\
\hline \multirow[t]{2}{*}{ C. owensensis } & $\mathrm{GH} 1$ & pNPGlu & 1.52 & 4027 & 3750.6 & 2467.5 & $75-85$ & 5.5 & This work \\
\hline & & Cellobiose & 15.65 & 2424 & 2149 & 137.3 & & & \\
\hline \multirow[t]{2}{*}{ C. bescii } & $\mathrm{GH} 1$ & pNPGlu & 3.71 & - & 311.6 & 84.0 & 85 & 6.8 & {$[9]$} \\
\hline & & Cellobiose & 90.8 & - & 757.9 & 8.35 & & & \\
\hline Neosartorya fischeri & $\mathrm{GH} 1$ & pNPGlu & 68 & 886 & 826.7 & 12.2 & 40 & 6 & {$[46]$} \\
\hline \multirow[t]{2}{*}{ Pholiota adipose } & $\mathrm{GH} 3$ & pNPGlu & 2.23 & 4390 & - & - & 65 & 5 & {$[28]$} \\
\hline & & Cellobiose & 5.60 & 3460 & - & - & & & \\
\hline Fomitopsis pinicola & $\mathrm{GH} 3$ & pNPGlu & 1.8 & 1710 & 2990 & 1700 & 50 & 4.5 & {$[47]$} \\
\hline Thermotoga petroph & $\mathrm{GH} 1$ & pNPGlu & 2.8 & 42,700 & 87,400 & 30,800 & $80-90$ & $7-8$ & {$[10]$} \\
\hline \multirow[t]{2}{*}{ Stereum hirsutum } & $\mathrm{GH1}$ & pNPGlu & 2.5 & 3028 & - & - & 65 & 4.5 & {$[48]$} \\
\hline & & Cellobiose & 86 & 172 & - & - & & & \\
\hline \multirow{2}{*}{$\begin{array}{l}\text { Talaromyces thermo- } \\
\text { philus }\end{array}$} & - & pNPGlu & 0.25 & 228.7 & - & - & 65 & 5.0 & {$[49]$} \\
\hline & & Cellobiose & 16.7 & 1519.1 & - & - & & & \\
\hline
\end{tabular}

OT optimum temperature; OP optimum $\mathrm{pH}_{;}-$no data 
activity of $1.9 \mathrm{U} \mathrm{mg}^{-1}$ against $p \mathrm{NPC}$ [32]. Lee et al. purified a cellobiohydrolase from Penicillium purpurogenum with a specific activity of $10.8 \mathrm{U} \mathrm{mg}^{-1}$ against $p \mathrm{NPC}$ $\mathrm{U} \mathrm{mg}^{-1}$ [33]. Bok et al. [11] purified two enzymes (CelA and $\mathrm{CelB}$ ) with both endo- and exoglucanase activities. The $V_{\max }$ of CelA and CelB were, respectively, 69.2 and $18.4 \mu \mathrm{mol} \mathrm{mg} \mathrm{min}^{-1} \mathrm{~min}^{-1}$ with $p \mathrm{NPC}$ as a substrate. The high specific activity against $p$ NPC indicates that the CoGH1A has high ability for split-off cellobiose or splitoff glucose one by one from $p$ NPC. However, using filter paper or cotton as the substrate the activities were very low ( $<0.1 \mathrm{U} \mathrm{mg}^{-1}$, Table 2). This is not surprising because the CoGH1A has only catalytic domain (CD) without carbohydrate-binding module (CBM) which would facilitate the enzyme binding to the substrate. Therefore, CoGH1A works primarily on soluble oligosaccharides.

$\beta$-galactosidases catalyze the hydrolysis of the $\beta-1$, 4-D glycosidic linkage of lactose and structurally related substrates. $\beta$-galactosidases have two main technological applications in the food industry, namely the removal of lactose from milk and dairy products [34] and the production of galactooligosaccharides (GalOS) from lactose by transglycosylation [3].

CoGH1A exhibits very high $\beta$-galactosidase activity with the catalytic coefficient $\left(k_{\text {cat }} / K_{\mathrm{m}}\right)$ of $7450.0 \mathrm{mM}^{-1} \mathrm{~s}^{-1}$ on $p$ NPGal. This is by far the highest catalytic coefficient for all reported $\beta$-galactosidases on $p$ NPGal (Table 5), much higher than the second high catalytic coefficient of $1462.8 \mathrm{mM}^{-1} \mathrm{~s}^{-1}$ by the enzyme from the thermoacidophilic bacterium Alicyclobacillus acidocaldarius [35]. The catalytic coefficient of another $\beta$-galactosidase from the same genus strain Caldicellulosiruptor saccharolyticus was $149 \mathrm{mM}^{-1} \mathrm{~s}^{-1}$ [21], much lower than that of CoGH1A, although the optimum temperature and $\mathrm{pH}$ between them are similar. Table 5 also shows that most of the $\beta$-galactosidases with higher activity belong to $\mathrm{GH} 1$. The optimum $\mathrm{pH}$ and temperature of these GH1 $\beta$-galactosidases are, respectively, 5.56.5 and $65-85{ }^{\circ} \mathrm{C}$. In general, the higher temperatures can be beneficial in higher oligosaccharide yields. The problem of microbial contamination can also be solved by increasing the catalysis temperature [34]. CoGH1A with high $\beta$-galactosidase activity and high optimum temperature $\left(75-85^{\circ} \mathrm{C}\right)$ will be a promising enzyme in the food industry.

\section{Supplementation of CoGH1 A for lignocellulosic biomass hydrolysis}

Based on the fact that CoGH1A is a multifunctional glycoside hydrolase, especially with high $\beta$-glucosidase activity, its capacity on saccharification of lignocellulosic biomass was determined. The experiment for hydrolysis of the steam-exploded (SE) corn stover by the commercial enzyme CTec2 (Novozymes) supplemented with CoGH1A was carried out at $60{ }^{\circ} \mathrm{C}$ and $\mathrm{pH}$ 5.5. As shown in Fig. 3, supplementation of CoGH1A could markedly enhance saccharification of the steam-exploded (SE) corn stover. Supplementing CoGH1A with the dose of 10 and $20 \mathrm{U}_{\text {cellobiose }} \mathrm{g}^{-1}$ biomass, after 72 -h hydrolysis, the concentrations of glucose increased from 1.95 (hydrolyzed by CTec 2 only) to 2.53 and $2.69 \mathrm{~g} \mathrm{~L}^{-1}$, increasing 29.7 and $37.9 \%$, respectively. In addition, the concentrations of xylose also increased from 0.38 to 0.47 and $0.54 \mathrm{~g} \mathrm{~L}^{-1}$, increasing 23.7 and $42.1 \%$, respectively. This indicates that CoGH1A contributed not only for cellulose but also for hemicellulose hydrolysis, due to its

Table 5 Kinetic parameters of CoGH1A and some reported microbial $\beta$-galactosidases with relatively high activity

\begin{tabular}{|c|c|c|c|c|c|c|c|c|c|}
\hline Resource & GH family & Substrate & $K_{\mathrm{m}}(\mathrm{mM})$ & $\begin{array}{l}V_{\max } \\
\left(\mu \mathrm{mol} \mathrm{mg}^{-1} \mathrm{~min}^{-1}\right)\end{array}$ & $k_{\text {cat }}\left(\mathrm{s}^{-1}\right)$ & $\begin{array}{l}k_{\mathrm{cat}} / K_{\mathrm{m}} \\
\left(\mathrm{mM}^{-1} \mathrm{~s}^{-1}\right)\end{array}$ & OT $\left({ }^{\circ} \mathrm{C}\right)$ & OP & Reference \\
\hline C. owensensis & $\mathrm{GH} 1$ & pNPGal & 0.607 & 5100 & 4522 & 7450 & $75-85$ & 5.5 & This work \\
\hline Alicyclobacillus acidocaldarius & $\mathrm{GH} 1$ & oNPGal & 5.50 & - & 8045.5 & 1462.8 & 65 & 5.5 & {$[35]$} \\
\hline Hot spring metagenome & $\mathrm{GH} 1$ & pNPGal & 3.33 & 40.00 & 2000.0 & 600.6 & 65 & 8.0 & {$[50]$} \\
\hline \multirow{2}{*}{$\begin{array}{l}\text { Lactobacillus delbrueckii subsp. } \\
\text { bulgaricus }\end{array}$} & \multirow{2}{*}{$\mathrm{GH} 2$} & oNPGal & 0.919 & 317 & 603 & 655 & \multirow[t]{2}{*}{$45-60$} & \multirow[t]{2}{*}{7.5} & \multirow[t]{2}{*}[23]{} \\
\hline & & Lactose & 19.2 & 123 & 234 & 12.3 & & & \\
\hline Bifidobacterium breve & $\mathrm{GH} 2$ & oNPGal & 1.3 & 486 & 937 & 722 & 50 & 7.0 & {$[51]$} \\
\hline Marine metagenomic library & $\mathrm{GH} 2$ & Lactose & 17.98 & - & 131.16 & 7.29 & 50 & 7.0 & {$[52]$} \\
\hline Bacillus licheniformis & $\mathrm{GH} 42$ & oNPGal & 13.7 & 299 & 785 & 57.3 & 50 & 6.5 & {$[53]$} \\
\hline \multirow[t]{2}{*}{ C. saccharolyticus } & \multirow[t]{2}{*}{$\mathrm{GH} 42$} & oNPGal & 1.21 & - & 149 & 123 & \multirow[t]{2}{*}{80} & \multirow[t]{2}{*}{6.0} & \multirow[t]{2}{*}[21]{} \\
\hline & & Lactose & 30.0 & - & 42 & 1.4 & & & \\
\hline \multirow[t]{2}{*}{ Thermotoga naphthophila } & \multirow[t]{2}{*}{$\mathrm{GH} 42$} & oNPGal & 1.31 & 3385.67 & - & - & 90 & 6.8 & \multirow[t]{2}{*}{ [13] } \\
\hline & & Lactose & 1.43 & 2.67 & - & - & 70 & 5.8 & \\
\hline Thermotoga maritima & $\mathrm{GH} 42$ & pNPGal & 2.74 & 351 & 5.85 & 2.13 & 80 & 5.5 & {$[54]$} \\
\hline
\end{tabular}

OT optimum temperature; OP optimum $\mathrm{pH}$; - no data 


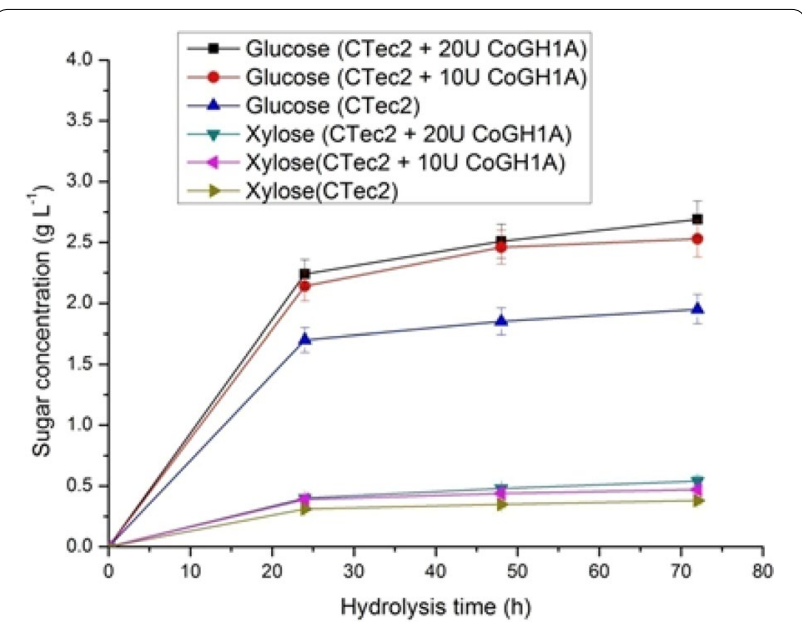

Fig. 3 Synergetic hydrolysis of steam-exploded corn stover by CTec2 and CoGH1A. This experiment was carried out in pH 5.5 acetate buffer at $60^{\circ} \mathrm{C}$ with the initial biomass of $20 \mathrm{~g} \mathrm{~L}^{-1}$. The $\mathrm{CTec} 2$ loading rate was $10 \mathrm{FPU} \mathrm{g}^{-1}$ biomass. The loading rate of the supplemented CoGH1A was 10 or $20 \mathrm{U}_{\text {cellobiose }} \mathrm{g}^{-1}$ biomass. Values are averages counted from three independent measures; error bars represent standard deviation

multi-activities on glycoside hydrolysis (Table 2 and $3)$. Although the catalytic temperature $60{ }^{\circ} \mathrm{C}$ in this experiment was not optimum for both $\mathrm{CTec} 2\left(50{ }^{\circ} \mathrm{C}\right)$ and CoGH1A $\left(75-85{ }^{\circ} \mathrm{C}\right)$, especially, the activity of CoGH1A at $60{ }^{\circ} \mathrm{C}$ was only about $50 \%$ of the maximum (Fig. 2), this experiment demonstrated the high ability of CoGH1A on saccharification of lignocellulosic biomass. CoGH1A, possessing $\beta$-glucosidase, exoglucanase, and $\beta$-xylosidase activities, may be a promising enzyme for industrial application in bioconversion of lignocellulosic biomass.

\section{Lactose transformation and synthesis}

\section{of galactooligosaccharides}

Since CoGH1A has very high $\beta$-galactosidase activity, its potential industrial applications were further investigated in low $\left(40 \mathrm{~g} \mathrm{~L}^{-1}\right)$ and high $\left(500 \mathrm{~g} \mathrm{~L}^{-1}\right)$ initial lactose concentrations by cultivating in $\mathrm{pH} 5.5$ citrate buffer at $70{ }^{\circ} \mathrm{C}$ with the enzyme dosage of $2.5 \mathrm{U}_{\text {lactose }} \mathrm{mL}^{-1}$. Figure 4a shows the time course of the enzymatic catalysis at the initial lactose concentration of $40 \mathrm{~g} \mathrm{~L}^{-1}$ which is very close to the concentration of lactose in fresh milk. After 10-min reaction, more than $83 \%$ of the lactose was degraded and the yields of GalOS, glucose, and galactose were $17.0,35.6$, and $30.6 \%$ with the concentrations of $6.80,14.24$, and $12.24 \mathrm{~g} \mathrm{~L}^{-1}$, respectively. When the reaction continued to $30 \mathrm{~min}$, about $92 \%$ of the lactose was converted and the yields of GalOS, glucose, and galactose were $11.0,41.9$, and $39.0 \%$ with the concentrations of $4.40,16.46$, and $15.6 \mathrm{~g} \mathrm{~L}^{-1}$, respectively. Further prolonging the reaction time, the concentrations of lactose and GalOS were gradually decreased, while the concentrations of glucose and galactose were gradually increased.

In literature, when the lactose hydrolysis rates reached $70-95 \%$, the reaction time needed is $2-10 \mathrm{~h}$ [34, 36-38]. However, in this research only 10 min was needed by CoGH1A. The high efficiency of CoGH1A makes it a potential candidate in milk and milk product industries. Moreover, CoGH1A has a function in the synthesis of GalOS, with 10-20\% GalOS yield during lactose hydrolysis. This will upgrade the quality and value of milk and milk products since GalOS are non-digestible oligosaccharides and are used as prebiotic food ingredients.

When the initial lactose concentration was $500 \mathrm{~g} \mathrm{~L}^{-1}$ (Fig. 4b), the GalOS yield was much higher than that with low initial lactose concentration $\left(40 \mathrm{~g} \mathrm{~L}^{-1}\right.$ Fig. $\left.4 \mathrm{a}\right)$. This
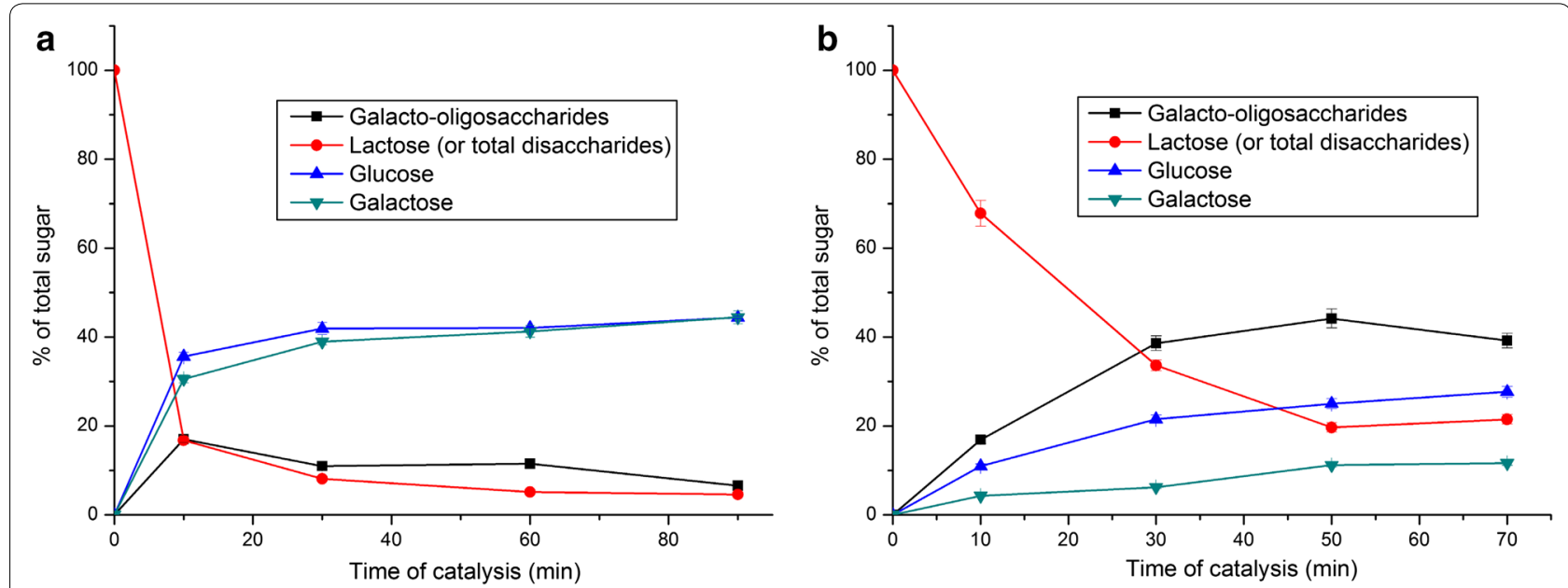

Fig. 4 Time course of the enzymatic catalysis of lactose degradation and GalOS synthesis by CoGH1A at the initial lactose concentration of $40 \mathrm{~g} \mathrm{~L}^{-1}$ (a) and $500 \mathrm{~g} \mathrm{~L}^{-1}$ (b). Values are averages counted from three independent measures; error bars represent standard deviation 
is in agreement with the fact that higher initial lactose concentrations can be beneficial in higher oligosaccharide yields [34]. The GalOS yield was $38.6 \%$ after 30-min catalysis and gradually increased to $44.2 \%$ at $50 \mathrm{~min}$. Further catalyzing for $70 \mathrm{~min}$, the GalOS yield was slightly decreased to $39.2 \%$. This indicated that reaction for $50 \mathrm{~min}$ is enough for achieving the highest GalOS yield. The highest GalOS concentration reached $221 \mathrm{~g} \mathrm{~L}^{-1}$ with a productivity of $265.2 \mathrm{~g} \mathrm{~L}^{-1} \mathrm{~h}^{-1}$.

Figure 4 also shows that at low initial lactose concentration (Fig. 4a) the glucose and galactose were the main products (totally about $80 \%$ ) and the yield of glucose was almost the same as that of galactose. This indicates that the velocity of lactose decomposition was much higher than that of GalOS synthesis in the condition of low initial lactose concentration. During the catalytic process at high initial lactose concentration (Fig. 4b), the concentration of lactose was quickly decreased. It was decreased more than $80 \%$ after $50 \mathrm{~min}$; however, the yield of galactose, which was produced from lactose decomposition, was kept below $11.6 \%$ because galactose was used for GalOS synthesis. It shows that the velocity of lactose decomposition was almost same as that of GalOS synthesis in the condition of high initial lactose concentration.

The characteristics of GalOS synthesis by CoGH1A at the initial lactose concentration of $500 \mathrm{~g} \mathrm{~L}^{-1}$ and some other $\beta$-galactosidases in batch process are shown in Table 6 . The GalOS productivity by CoGH1A was more than 12 times higher than that of the $\beta$-galactosidases from Lactobacillus delbrueckii subsp. Bulgaricus $\left(19.8 \mathrm{~g} \mathrm{~L}^{-1} \mathrm{~h}^{-1}\right)$ [23], Bifidobacterium breve $\left(14.7 \mathrm{~g} \mathrm{~L}^{-1} \mathrm{~h}^{-1}\right)$ [51], marine metagenomic library $\left(20.6 \mathrm{~g} \mathrm{~L}^{-1} \mathrm{~h}^{-1}\right)$ [52], and Thermotoga maritima (18.20 $\left.\mathrm{g} \mathrm{L}^{-1} \mathrm{~h}^{-1}\right)$ [39]. Time for reaching the maximum yield by the four $\beta$-galactosidases was 5-10 h (Table 6), which is at least fivefold longer than that by CoGH1A. Although the enzyme loading rate of CoGH1A $\left(2.5 \mathrm{U}_{\text {lactose }} \mathrm{mL}^{-1}\right)$ in this study was higher than that from Lactobacillus delbrueckii subsp. bulgaricus $\left(1.5 \mathrm{U}_{\text {lactose }} \mathrm{mL}^{-1}\right)$ and Thermotoga maritima $\left(1.5 \mathrm{U}_{\text {lac- }}\right.$ tose $\mathrm{mL}^{-1}$ ), the actual protein loading rate of CoGH1A was $8.9 \mu \mathrm{g} \mathrm{mL}^{-1}$ which was much lower than those of other $\beta$-galactosidases (Table 6). Moreover, CoGH1A has high thermostability with retaining $100 \%$ activity after incubation at $75{ }^{\circ} \mathrm{C}$ for $12 \mathrm{~h}$ (Fig. 2c). The problem of microbial contamination can also be alleviated or avoided at such a high temperature. These advantages of CoGH1A make it a potential candidate for $\mathrm{GalOS}$ synthesis.

\section{Multiple sequence alignment and the possible role in host bacterium}

The structure and active site residues of the enzyme were predicted for analyzing the difference between CoGH1A and other GHs whose structures were resolved. Three proteins with relatively higher identity to CoGH1A were found, i.e., 3AHX (a $\beta$-glucosidase from Clostridium cellulovorans) [40], 4PTV (a $\beta$-glucosidase from Halothermothrix orenii) [41], and 1OD0 (a $\beta$-glucosidase from Thermotoga maritima) [42]. CoGH1A shares, respectively, 53,50 , and $48 \%$ identity with them. However, the catalytic coefficients $\left(k_{\mathrm{cat}} / K_{\mathrm{m}}\right)$ of 3AHX, 4PTV, and 1OD0 were, respectively, 340, 187, and $102 \mathrm{mM}^{-1} \mathrm{~s}^{-1}$ with $p$ NPGlu (for 3AHX and 4PTV) [40, 41] or 2, 4-dinitrophenyl- $\beta$-Dglucopyranoside (for 1OD0) [42] as a substrate. They are much lower than those of CoGH1A. Multiple sequence alignment of CoGH1A with the aforesaid proteins (Fig. 5) was performed using the ClustalX2 software and depicted online by ESPrit 3.0 (http://www.espript.ibcp.fr/). The catalytic acid/base and catalytic nucleophile of CoGH1A are predicted as Glu163 and Glu361 (pointed out by blue arrows in Fig. 5), respectively. The residual Glu414 is predicted to be participated in substrate binding. As Fig. 5 shows, both the catalytic glutamic acid residues and the amino acid residues next to them are conserved among the four enzymes. This suggests that the catalytic coefficients

Table 6 Characteristic of GalOS synthesis by different $\beta$-galactosidases in batch process

\begin{tabular}{|c|c|c|c|c|c|c|c|c|}
\hline \multirow{2}{*}{$\begin{array}{l}\text { Enzyme source } \\
\text { Lactobacillus } \\
\text { delbrueckii subsp. } \\
\text { bulgaricus }\end{array}$} & \multirow{2}{*}{$\begin{array}{l}\begin{array}{l}\text { Initial lactose } \\
\text { concentration } \\
\left(\mathrm{g} \mathrm{L}^{-1}\right)\end{array} \\
205\end{array}$} & \multicolumn{2}{|c|}{$\begin{array}{l}\text { Enzyme } \\
\text { loading }\left(U_{\text {lactose }}\right. \\
\left.\mathrm{ml}^{-1} \mu \mathrm{gl}^{-1}\right)\end{array}$} & \multirow{2}{*}{$\begin{array}{l}\text { Temperature }\left({ }^{\circ} \mathrm{C}\right) \\
50\end{array}$} & \multirow{2}{*}{$\begin{array}{l}\text { Time for reaching } \\
\text { maximum yield } \\
5 \mathrm{~h}\end{array}$} & \multirow{2}{*}{$\begin{array}{l}\text { GalOS productiv- } \\
\text { ity }\left(\mathbf{g ~ L}^{-1} \mathbf{h}^{-1}\right) \\
19.8\end{array}$} & \multirow{2}{*}{$\begin{array}{l}\begin{array}{l}\text { Maximum } \\
\text { yield of } \\
\text { GalOS \% }\end{array} \\
\sim 50\end{array}$} & \multirow{2}{*}{$\begin{array}{l}\text { References } \\
{[23]}\end{array}$} \\
\hline & & 1.5 & $>12.2^{\mathrm{a}}$ & & & & & \\
\hline Bifidobacterium breve & 200 & 2.5 & $>25.8^{\mathrm{a}}$ & 30 & $6 \mathrm{~h}$ & 14.7 & 44 & [51] \\
\hline $\begin{array}{l}\text { Thermotoga } \\
\text { maritima }\end{array}$ & 500 & 1.5 & $>23.6^{\mathrm{a}}$ & 80 & $5 \mathrm{~h}$ & 18.2 & 18 & {$[39,55]$} \\
\hline $\begin{array}{l}\text { Marine metagenomic } \\
\text { library }\end{array}$ & 360 & 18 & 267.9 & 40 & $\sim 10 \mathrm{~h}$ & 20.6 & 57.1 & {$[52]$} \\
\hline $\begin{array}{l}\text { Caldicellulosiruptor } \\
\text { owensensis }\end{array}$ & 500 & 2.5 & 8.9 & 70 & $50 \mathrm{~min}$ & 265.2 & 44.2 & This work \\
\hline
\end{tabular}

\footnotetext{
a The given data were calculated using the values of the $V_{\max }$ of each enzyme as the specific activity
} 


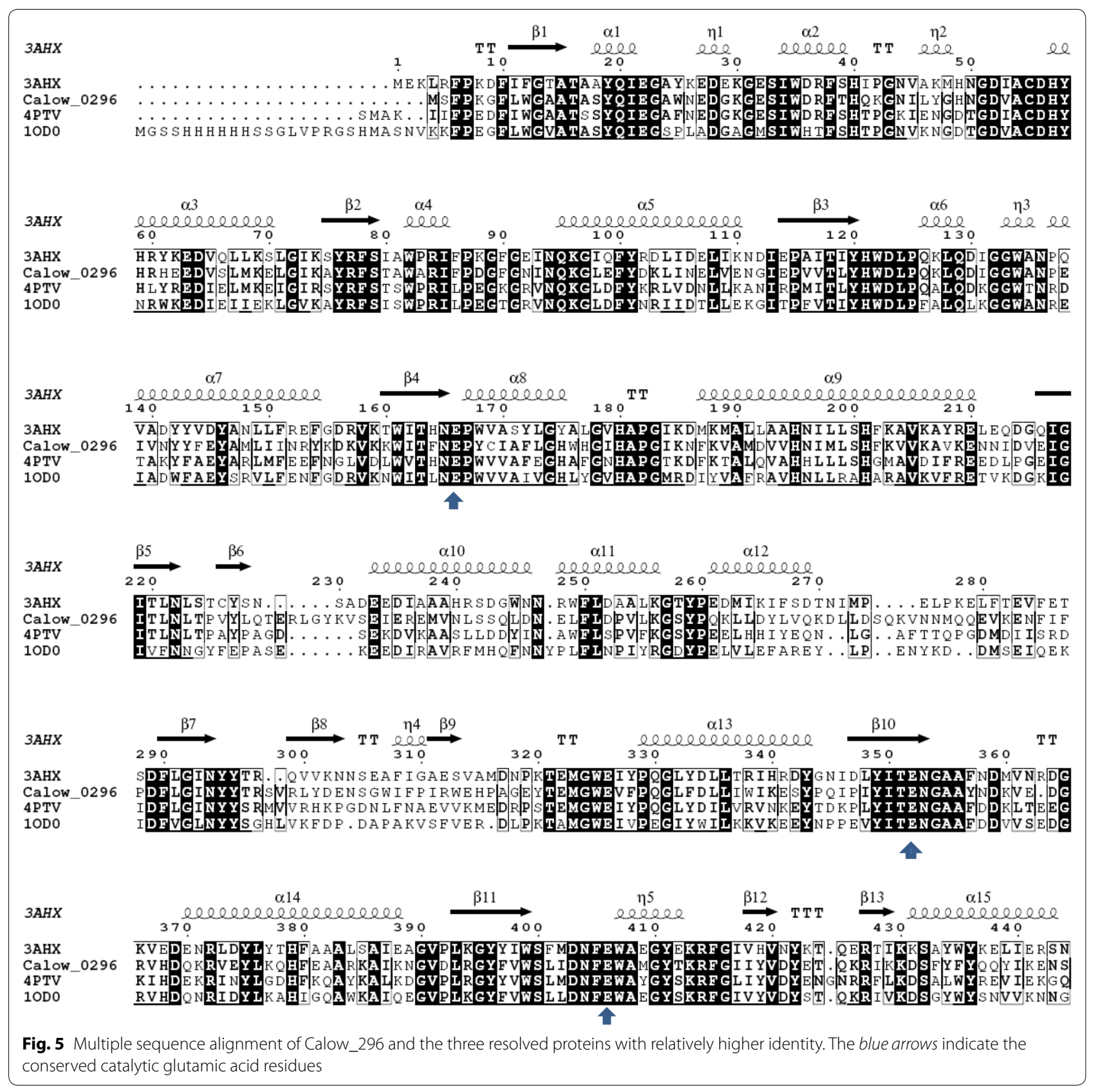

of these enzymes are determined by the amino acid sequences except the conserved catalytic glutamic acids.

Caldicellulosiruptor owensensis, the host bacterium of CoGH1A, was isolated from a shallow freshwater pond located in the Owens Lake bed area [20]. It could grow on a wide variety of carbon sources including arabinose, glucose, cellobiose, cellulose, xylan, xylose, galactose, dextrin, fructose, lactose, glycogen, inositol, mannitol, mannose, maltose, pectin, raffinose, rhamnose, ribose, starch, sucrose, and tagatose [20]. In its growing environment, the polysaccharides (or glycans) may be the most possible carbon sources that $C$. owensensis could be obtained. Decomposition of these polysaccharides to monoses is necessary for $C$. owensensis to assimilate them. The multifunctional glycoside hydrolase CoGH1A, which could efficiently convert various soluble oligosaccharides to monoses, may give important contribution to $C$. owensensis for its capability of utilizing the wide variety of carbon sources. The thermostability of CoGH1A and its resistance to cations may also help the host bacterium growing in the changeful environments. 


\section{Conclusions}

A multifunctional glycoside hydrolase, named CoGH1A, has been cloned and expressed from the extremely thermophilic bacterium $C$. owensensis. It possesses high activities of $\beta$-D-glucosidase, exoglucanase, $\beta$-Dxylosidase, $\beta$-D-galactosidase, and transgalactosylation. Moreover, it exerts excellent thermostability by retaining $100 \%$ activity after $12-\mathrm{h}$ incubation at $75{ }^{\circ} \mathrm{C}$. The enzyme contributed not only for glucose but also for xylose release when it was supplemented for hydrolysis of corn stover. Additionally, the catalytic efficiencies of this enzyme on lactose decomposition and galactooligosaccharides synthesis were at least, respectively, 5- and 12 -fold those of the reported glycoside hydrolases. The multifunctional glycoside hydrolase CoGH1A is a promising enzyme to be used for bioconversion of biomass and carbohydrate. This research also indicates that the extremely thermophilic bacteria are potential resources for screening highly efficient GHs for the production of biofuels and biochemicals.

\section{Methods \\ Materials}

The extremely thermophilic cellulolytic bacteria C. owensensis DSM 13,100 was purchased from the DSMZ (German Collection of Microorganisms and Cell Cultures). The substrates, $p$-nitrophenyl $\beta$-D-galactopyranoside $(p$ NPGal), $\quad p$-nitrophenyl $\beta$-D-glucopyranoside ( $p$ NPGlu), $p$-nitrophenyl $\beta$-D-cellobioside ( $p$ NPC), $p$-nitrophenyl $\beta$-D-xylopyranoside ( $p$ NPX), $\quad p$-nitrophenyl $\beta$-D-mannopyranoside ( $p$ NPM $), \quad p$-nitrophenyl $\alpha$-Larabinofuranoside ( $p$ NPAr), carboxymethylcellulose (CMC), locust bean gum, and synanthrin, were purchased from Sigma. The chemicals and other substrates were purchased from Sinopharm Chemical Reagent Beijing Co., Ltd or Sigma. The steam-exploded corn straw was obtained by being pretreated in the condition of 1.5 $\mathrm{MPa}$ retained for $3 \mathrm{~min}$. Its composition was glucan $46.8 \%$, xylan $4.3 \%$, araban $0 \%$, and lignin $27.4 \%$. Competent cells used for cloning and expression were Escherichia coli Top10 (TianGen, China) and E. coli BL21 (DE3), respectively. The E.coli BL21 (DE3) competent cells were prepared with the methods described in Molecular Cloning: A Laboratory Manual [43].

\section{Cloning the gene of CoGH1A}

Caldicellulosiruptor owensensis cells were inoculated at $75{ }^{\circ} \mathrm{C}, 75 \mathrm{rpm}$ for $24 \mathrm{~h}$ with the DSMZ medium 640 (detailed list of ingredient was supplied by DSMZ, http://www.dsmz.de). The genomic DNA of C. owensensis was extracted from $3 \mathrm{~mL}$ of fermentation broth using TIANamp Bacteria DNA Kit (TianGen, China).
Gene Calow_0296 was amplified from the genomic DNA of C. owensensis using the primers of CoGH1AF 5'-GCCGCGCGGCAGCATGAGTTTTCCAAAAG-3' and CoGH1A-R 5'-GCG GCCGCAAGCGTTTATGAATTT TCCTTTAT-3'. The PCR product was then purified and separately treated with $0.5 \mathrm{IU}$ of T4 DNA polymerase (Takara) and $5 \mathrm{mM}$ dATP at $37^{\circ} \mathrm{C}$ for $30 \mathrm{~min}$. T4 DNA polymerase was then inactivated by incubating at $75{ }^{\circ} \mathrm{C}$ for $20 \mathrm{~min}$, and vector pETke and the treated insert gene were annealed at $22{ }^{\circ} \mathrm{C}$ for $15 \mathrm{~min}$. After that, recombinant plasmids were transferred into TOP10 competent cells, and then cultured by Lysogeny Broth (LB) agar plates with kanamycin $\left(50 \mu \mathrm{g} \mathrm{m}^{-1}\right)$. After colony PCR and sequencing validation (Sangon, Shanghai, China), target fragments were proved to have imported into the vectors. Then positive recombinant plasmid was extracted by TIAN prep Mini Plasmid Kit (TianGen) and transformed into E. coli BL21 (DE3).

\section{Heterologous expression and purification of CoGH1 A}

The transformed cells were incubated overnight on LB agar plate with kanamycin at $37{ }^{\circ} \mathrm{C}$. Single colony was picked from the plate and cultivated in liquid LB medium with kanamycin in an incubator shaker $\left(220 \mathrm{rpm}, 37^{\circ} \mathrm{C}\right)$ for $12 \mathrm{~h}$. The recombinant bacteria were inoculated into fresh liquid LB medium (1 L) with kanamycin and incubated in the incubator shaker $\left(220 \mathrm{rpm}, 37^{\circ} \mathrm{C}\right.$ ) till OD600 of about $0.6-0.8$. Then the isopropyl-d-thiogalactopyranoside (IPTG) with a final concentration of $0.1 \mathrm{mM}$ was added to the broth for further 12 -h cultivation at the conditions of $16^{\circ} \mathrm{C}$ and $160 \mathrm{rpm}$. Cells were collected and resuspended in lysis buffer (50 mM Tris- $\mathrm{HCl}, \mathrm{pH} 7.5,300 \mathrm{mM} \mathrm{NaCl}$ ), and then lysed at $4{ }^{\circ} \mathrm{C}$ by Selecta Sonopuls (JY92-IN, Ningbo Scientz Biotechnology, Ningbo, China). After centrifugation (20,000 rpm for $20 \mathrm{~min})$, the supernatant was applied to a His-Tag Ni-affinity resin (National Engineering Research Centre for Biotechnology, Beijing, China) pre-equilibrated with binding buffer $(50 \mathrm{mM}$ Tris- $\mathrm{HCl} \mathrm{pH} \mathrm{7.5,} 300 \mathrm{mM} \mathrm{NaCl}$ ). The column was washed with $10 \mathrm{~mL}$ binding buffer to remove the nonassociative proteins. Fusion protein $(\mathrm{CoGH} 1 \mathrm{~A})$ was eluted by elution buffer $(50 \mathrm{mM}$ Tris- $\mathrm{HCl}, \mathrm{pH} 7.5,300 \mathrm{mM}$ $\mathrm{NaCl}$ and $150 \mathrm{mM}$ imidazole). The purified CoGH1A was confirmed by sodium dodecyl sulfate-polyacrylamide gel electrophoresis (SDS-PAGE). The protein concentration was measured as described by Bradford [44] using bovine serum albumin as standard. The quaternary structure of purified CoGH1A was analyzed through gel filtration chromatography. The molecular mass (MW) was estimated by the calibration curve of $\log (\mathrm{MW})$ vs. elution volume. 


\section{Assay activities of CoGH1A on different substrates}

Substrate specificity of the CoGH1A was estimated by incubating the diluted enzyme in $50 \mathrm{mM}$ citrate buffer (pH 6.0) containing $1 \mathrm{mM} p$-nitrophenol-glycosides ( $p$ NPGal, $p$ NPGlu, $p$ NPC, $p$ NPX, $p$ NPAr, or $p$ NPM) or disaccharides (cellobiose or lactose) or $1 \%(\mathrm{w} / \mathrm{v})$ glycan (locust bean gum, synanthrin, cotton, filter paper, or carboxymethyl cellulose) at $75{ }^{\circ} \mathrm{C}$ for $5-30 \mathrm{~min}$. The released $p$-nitrophenol (from $p$-nitrophenol-glycosides), glucose (from cellobiose and lactose), and reducing sugars (from glycans) were, respectively, measured by spectrophotometer (at $400 \mathrm{~nm}$ ) [16], high-performance liquid chromatography (HPLC), and DNS method [45]. One unit of enzyme activity was defined as the amount of protein capable of releasing $1 \mu \mathrm{mol} p \mathrm{NP}$, glucose, or reducing sugars from the substrates (releasing $2 \mu \mathrm{mol}$ glucose from cellobiose) per minute.

\section{Characterization of CoGH1A}

The optimum $\mathrm{pH}$ for CoGH1A was determined in the range of $4-8$ at the temperature of $75{ }^{\circ} \mathrm{C}$ in citrate buffer. The optimum temperature for CoGH1A was determined
LC-20AT (Shimadzu, Japan) and a refractive index detector (RID-10A, Shimadzu, Japan). A Hi-Plex Ca column $(7.7 \times 300 \mathrm{~mm}$, Agilent Technology, USA) was used for the HPLC analysis. HPLC-grade water was used as the mobile phase at a flow rate of $0.6 \mathrm{~mL} \mathrm{~min}^{-1}$ at $85{ }^{\circ} \mathrm{C}$.

\section{Lactose hydrolysis and transgalactosylation}

Lactose hydrolysis and transgalactosylation by CoGH1A were carried out, respectively, at the initial lactose concentrations of 40 and $500 \mathrm{~g} \mathrm{~L}^{-1}$, in citrate buffer of $\mathrm{pH}$ 5.5 at $70{ }^{\circ} \mathrm{C}$ with the $\beta$-galactosidase dosage of $2.5 \mathrm{U}_{\text {lactose }}$ $\mathrm{mL}^{-1}$. Quantitative analysis of the sugars was carried out by HPLC. Glucose, galactose, and lactose in the mixtures were identified by comparison of their retention times with those of the standards and quantified from the peak area calibrated against sugar standards. In this HPLC experiment, the disaccharides such as lactose, galactobiose, and allolactose could not be separated. The retention time of these disaccharides was almost the same. Therefore, the total disaccharides were quantified using the lactose as standard. The GalOS yield was calculated according to the following formula:

GalOS yield $(\%)=\frac{\text { mass of initial lactose }- \text { mass of }(\text { disaccharides }+ \text { glucose }+ \text { galactose })}{\text { mass of initial lactose }} \times 100 \%$.

in the range of $40-100{ }^{\circ} \mathrm{C}$ at the pH 5.5 in citrate buffer. Thermostability was investigated after incubation of the samples at different temperatures in pH 5.5 citrate buffer. Samples were withdrawn at appropriate time intervals and the residual activity was measured as described above. The effects of metal ions on CoGH1A activity were determined at $75{ }^{\circ} \mathrm{C}$ and $\mathrm{pH} 5.5$. The $p$ NPGal with the concentration of $1 \mathrm{mM}$ was used as a substrate. The kinetic parameters on the substrates of $p$ NPGal, $p$ NPGlu, $p$ NPC, $p$ NPX, and cellobiose were analyzed at $75^{\circ} \mathrm{C}$ and $\mathrm{pH} 5.5$ using various concentrations of each substrate for enzyme activity assay.

\section{Hydrolysis of the steam-exploded corn stover}

Synergetic hydrolysis by the commercial enzyme cocktail Cellic CTec2 (Novozymes) and CoGH1A was carried out in $\mathrm{pH} 5.5$ acetate buffer with the initial steam-exploded corn stover concentration of $20 \mathrm{~g} \mathrm{~L}^{-1}$. The reaction volume was $1 \mathrm{~mL}$ in a $2-\mathrm{mL}$ Eppendorf tube, which was sealed by winding parafilm after closing the lip, and put in a water bath at $60{ }^{\circ} \mathrm{C}$ for $72 \mathrm{~h}$. The loading rates of CTec 2 and $\mathrm{CoGH} 1 \mathrm{~A}$ were, respectively, $10 \mathrm{FPU} \mathrm{g}^{-1}$ biomass and 10 or $20 \mathrm{U}_{\text {cellobiose }} \mathrm{g}^{-1}$ biomass. Hydrolysis of steam-exploded corn stover using CTec2 alone in the same condition was implemented as a control. The produced sugars were quantified by high-performance liquid chromatography (HPLC) with a pump of
This formula is based on the fact that the sum of all sugars (glucose, galactose, disaccharides, and GalOS) was approximately equal to that of initial lactose [52]. According to this formula, the GalOS yields given in this work do not include the disaccharides.

\section{Structure and active site prediction}

The structure and active site were predicted for analyzing the difference between CoGH1A and other GHs whose structures were resolved. The amino acid sequence of CoGH1A was blasted in the Protein Data Bank (PDB) database (http://www.rcsb.org).

Multiple sequence alignment of CoGH1A with the resolved proteins was performed using the ClustalX2 software and depicted online by ESPrit 3.0 (http://www. espript.ibcp.fr/).

\section{Abbreviations}

GH: glycoside hydrolase; FPA: filter paper activity; CMC: carboxymethylcellulose; $p$ NPGal: $p$-nitrophenyl $\beta$-D-galactopyranoside; $p N P G l u: p$-nitrophenyl $\beta$-D-glucopyranoside; $p N P C: p$-nitrophenyl $\beta$-D-cellobioside; $p N P X: p$-nitrophenyl $\beta$-D-xylopyranoside; $p$ NPM: $p$-nitrophenyl $\beta$-D-mannopyranoside; $p$ NPAr: $p$-nitrophenyl a-L-arabinofuranoside; HPLC: high-performance liquid chromatography; GalOS: galactooligosaccharides.

\section{Authors' contributions}

$\mathrm{XP}$ and $\mathrm{YH}$ designed the study. XP performed all the experiments, analyzed the data, and drafted the manuscript. HS participated in structure analysis. SM participated in DNA extraction. All authors read and approved the final manuscript. 


\section{Acknowledgements}

We would like to thank the financial support from the National High Technology Research and Development Program of China (863 Project No: 2014AA021905) and 100 Talents Program of Institute of Process Engineering, Chinese Academy of Sciences.

\section{Competing interests}

The authors declare that they have no competing interests.

Received: 5 January 2016 Accepted: 14 April 2016

Published online: 30 April 2016

\section{References}

1. Garvey M, Klose H, Fischer R, et al. Cellulases for biomass degradation: comparing recombinant cellulase expression platforms. Trends Biotechnol. 2013;31:581-93.

2. Reyes-Ortiz V, Heins RA, Cheng G, et al. Addition of a carbohydratebinding module enhances cellulase penetration into cellulose substrates. Biotechnol Biofuels. 2013;6:1-13.

3. Park AR, Oh DK. Galacto-oligosaccharide production using microbial $\beta$-galactosidase: current state and perspectives. Appl Microbiol Biotechnol. 2010;85:1279-86.

4. Zou ZZ, Yu HL, Li CX, et al. A new thermostable $\beta$-glucosidase mined from Dictyoglomus thermophilum: properties and performance in octyl glucoside synthesis at high temperatures. Bioresour Technol. 2012;118:425-30.

5. Bauer MW, Driskill LE, Kelly RM. Glycosyl hydrolases from hyperthermophilic microorganisms. Curr Opin Biotechnol. 1998;9:141-5.

6. Blumer-Schuette SE, Kataeva I, Westpheling J, et al. Extremely thermophilic microorganisms for biomass conversion: status and prospects. Curr Opin Biotechnol. 2008;19:210-7.

7. Blumer-Schuette SE, Giannone RJ, Zurawski JV, et al. Caldicellulosiruptor core and pangenomes reveal determinants for noncellulosomal thermophilic deconstruction of plant biomass. J Bacteriol. 2012;194:4015-28.

8. Bhalla A, Bansal N, Kumar S, et al. Improved lignocellulose conversion to biofuels with thermophilic bacteria and thermostable enzymes. Bioresour Technol. 2013;128:751-9.

9. Bai A, Zhao X, Jin Y, et al. A novel thermophilic $\beta$-glucosidase from Caldicellulosiruptor bescii: characterization and its synergistic catalysis with other cellulases. J Mol Catal B Enzym. 2013;85:248-56.

10. Haq IU, Khan MA, Muneer B, et al. Cloning, characterization and molecular docking of a highly thermostable $\beta$-1, 4-glucosidase from Thermotoga petrophila. Biotechnol Lett. 2012;34:1703-9.

11. Bok JD, Yernool DA, Eveleigh DE. Purification, characterization, and molecular analysis of thermostable cellulases CelA and CelB from Thermotoga neapolitana. Appl Environ Microbiol. 1998;64:4774-81.

12. Mi S, Jia X, Wang J, et al. Biochemical characterization of two thermostable xylanolytic enzymes encoded by a gene cluster of Caldicellulosiruptor owensensis. PLoS One. 2014;9:e106482.

13. Kong F, Wang Y, Cao S, et al. Cloning, purification and characterization of a thermostable $\beta$-galactosidase from Thermotoga naphthophila RUK-10. Process Biochem. 2014;49:775-82.

14. Blumer-Schuette SE, Lewis DL, Kelly RM. Phylogenetic, microbiological, and glycoside hydrolase diversities within the extremely thermophilic, plant biomass-degrading genus Caldicellulosiruptor. Appl Environ Microbiol. 2010;76:8084-92.

15. Blumer-Schuette SE, Ozdemir I, Mistry D, et al. Complete genome sequences for the anaerobic, extremely thermophilic plant biomassdegrading bacteria Caldicellulosiruptor hydrothermalis, Caldicellulosiruptor kristjanssonii, Caldicellulosiruptor kronotskyensis, Caldicellulosiruptor owensenis and Caldicellulosiruptor lactoaceticus. J Bacteriol. 2011;193:1483-4.

16. Peng X, Qiao W, Mi S, et al. Characterization of hemicellulase and cellulase from the extremely thermophilic bacterium Caldicellulosiruptor owensensis and their potential application for bioconversion of lignocellulosic biomass without pretreatment. Biotechnol Biofuels. 2015;8:131.

17. Brunecky R, Alahuhta M, Xu Q, et al. Revealing nature's cellulase diversity: the digestion mechanism of Caldicellulosiruptor bescii CelA. Science. 2013;342:1513-6.
18. Uchima C, Tokuda G, Watanabe H, Kitamoto K, Arioka M. Heterologous expression in Pichia pastoris and characterization of an endogenous thermostable and high-glucose-tolerant $\beta$-glucosidase from the termite Nasutitermes takasagoensis. Appl Environ Microbiol. 2012;78(12):4288-93.

19. Parry N, Beever D, Owen E, Vandenberghe I, Beeumen J, Bhat M. Biochemical characterization and mechanism of action of a thermostable $\beta$-glucosidase purified from Thermoascus aurantiacus. Biochem J. 2001;353:117-27.

20. Huang C-Y, Patel BK, Mah RA, Baresi L. Caldicellulosiruptor owensensis sp. nov., an anaerobic, extremely thermophilic, xylanolytic bacterium. Int J Syst Bacteriol. 1998:48:91-7.

21. Park AR, Oh DK. Effects of galactose and glucose on the hydrolysis reaction of a thermostable $\beta$-galactosidase from Caldicellulosiruptor saccharolyticus. Appl Microbiol Biotechnol. 2010;85:1427-35.

22. Qiao W, Tang S, Mi S, Jia X, Peng X, Han Y. Biochemical characterization of a novel thermostable GH11 xylanase with CBM6 domain from Caldicellulosiruptor kronotskyensis. J Mol Catal B Enzym. 2014;107:8-16.

23. Nguyen TT, Nguyen HA, Arreola SL, et al. Homodimeric $\beta$-galactosidase from Lactobacillus delbrueckii subsp. bulgaricus DSM 20081: expression in Lactobacillus plantarum and biochemical characterization. J Agric Food Chem. 2012;60:1713-21.

24. Zhang YHP, Himmel ME, Mielenz JR. Outlook for cellulase improvement: screening and selection strategies. Biotechnol Adv. 2006;24:452-81.

25. Bhatia Y, Mishra S, Bisaria V. Microbial $\beta$-glucosidases: cloning, properties, and applications. Crit Rev Biotechnol. 2002;22:375-407.

26. Merino ST, Cherry J. Progress and challenges in enzyme development for biomass utilization. Adv Biochem Eng Biotechnol. 2007;108:95-120.

27. Gusakov AV. Alternatives to Trichoderma reesei in biofuel production. Trends Biotechnol. 2011;29:419-25.

28. Jagtap SS, Dhiman SS, Kim TS, et al. Characterization of a $\beta-1$, 4-glucosidase from a newly isolated strain of Pholiota adiposa and its application to the hydrolysis of biomass. Biomass Bioenerg. 2013;54:181-90.

29. Divne C, Stahlberg J, Reinikainen T, et al. The three-dimensional crystal structure of the catalytic core of cellobiohydrolase I from Trichoderma reesei. Science. 1994;265:524-8.

30. Rouvinen J, Bergfors T, Teeri T, et al. Three-dimensional structure of cellobiohydrolase II from Trichoderma reesei. Science. 1990;249:380-6.

31. Segato F, Damasio A, Gonçalves TA, et al. Two structurally discrete GH7-cellobiohydrolases compete for the same cellulosic substrate fiber. Biotechnol Biofuels. 2012;5:21.

32. Gao L, Wang F, Gao F, et al. Purification and characterization of a novel cellobiohydrolase (PdCel6A) from Penicillium decumbens JU-A10 for bioethanol production. Bioresour Technol. 2011;102:8339-42.

33. Lee KM, Joo AR, Jeya M, et al. Production and characterization of cellobiohydrolase from a novel strain of Penicillium purpurogenum KJS506. Appl Biochem Biotechnol. 2011;163:25-39.

34. Panesar PS, Kumari S, Panesar R. Potential applications of immobilized $\beta$-galactosidase in food processing industries. Enzyme Res. 2010;2010:473137.

35. Di Lauro B, Rossi M, Moracci M. Characterization of a $\beta$-glycosidase from the thermoacidophilic bacterium Alicyclobacillus acidocaldarius. Extremophiles. 2006;10:301-10.

36. Li X, Zhou QZ, Chen XD. Pilot-scale lactose hydrolysis using $\beta$-galactosidase immobilized on cotton fabric. Chem Eng Process Process Intensif. 2007:46:497-500.

37. Roy I, Gupta MN. Lactose hydrolysis by Lactozym ${ }^{\mathrm{TM}}$ immobilized on cellulose beads in batch and fluidized bed modes. Process Biochem. 2003:39:325-32.

38. Haider T, Husain Q. Immobilization of $\beta$-galactosidase by bioaffinity adsorption on concanavalin A layered calcium alginate-starch hybrid beads for the hydrolysis of lactose from whey/milk. Int Dairy J. 2009;19:172-7.

39. Ji ES, Park NH, Oh DK. Galacto-oligosaccharide production by a thermostable recombinant $\beta$-galactosidase from Thermotoga maritima. World J Microbiol Biotechnol. 2005;21:759-64.

40. Jeng $W Y$, Wang $N C$, Lin $M H$, et al. Structural and functional analysis of three $\beta$-glucosidases from bacterium Clostridium cellulovorans, fungus Trichoderma reesei and termite Neotermes koshunensis. J Struct Biol. 2011;173:46-56.

41. Hassan N, Nguyen T-H, Intanon M, et al. Biochemical and structural characterization of a thermostable $\beta$-glucosidase from Halothermothrix orenii for galacto-oligosaccharide synthesis. Appl Microbiol Biotechnol. 2015:99:1731-44. 
42. Zechel DL, Boraston AB, Gloster T, et al. Iminosugar glycosidase inhibitors: structural and thermodynamic dissection of the binding of isofagomine and 1-deoxynojirimycin to $\beta$-glucosidases. J Am Chem Soc. 2003;125:14313-23.

43. Green MR, Sambrook J. Molecular cloning: a laboratory manual. New York: Cold Spring Harbor Laboratory Press; 2012.

44. Bradford MM. A rapid and sensitive method for the quantitation of microgram quantities of protein utilizing the principle of protein-dye binding. Anal Biochem. 1976;72:248-54.

45. Miller GL. Use of dinitrosalicylic acid reagent for determination of reducing sugar. Anal Chem. 1959:31:426-8.

46. Tiwari MK, Lee KM, Kalyani D, et al. Role of Glu445 in the substrate binding of $\beta$-glucosidase. Process Biochem. 2012;47:2365-72.

47. Joo AR, Jeya M, Lee KM, et al. Purification and characterization of a $\beta-1$, 4-glucosidase from a newly isolated strain of Fomitopsis pinicola. Appl Microbiol Biotechnol. 2009;83:285-94.

48. Lee KM, Lee KM, Kim IW, et al. One-step purification and characterization

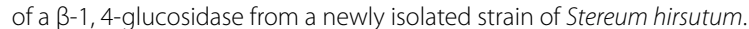
Appl Microbiol Biotechnol. 2010;87:2107-16.

49. Mallek-Fakhfakh H, Belghith H. Physicochemical properties of thermotolerant extracellular $\beta$-glucosidase from Talaromyces thermophilus and enzymatic synthesis of cello-oligosaccharides. Carbohydr Res. 2016;419:41-50
50. Gupta R, Govil T, Capalash N, Sharma P. Characterization of a glycoside hydrolase family $1 \beta$-galactosidase from hot spring metagenome with transglycosylation activity. Appl Biochem Biotechnol. 2012;168:1681-93.

51. Arreola SL, Intanon M, Suljic J, et al. Two $\beta$-galactosidases from the human isolate Bifidobacterium breve DSM 20213: molecular cloning and expression, biochemical characterization and synthesis of galacto-oligosaccharides. PLoS One. 2014;9(8):e104056.

52. Li L, Li G, Cao L, et al. Characterization of the cross-linked enzyme aggregates of a novel $\beta$-galactosidase, a potential catalyst for the synthesis of galacto-oligosaccharides. J Agric Food Chem. 2015;63:894-901.

53. Juajun $\mathrm{O}, \mathrm{Nguyen} \mathrm{TH}$, Maischberger $\mathrm{T}$, et al. Cloning, purification, and characterization of $\beta$-galactosidase from Bacillus licheniformis DSM 13. App Microbiol Biotechnol. 2011;89:645-54

54. Li L, Zhang M, Jiang $Z$, et al. Characterisation of a thermostable family $42 \beta$-galactosidase from Thermotoga maritima. Food Chem. 2009;112:844-50

55. Kim C, Ji ES, Oh DK. Characterization of a thermostable recombinant $\beta$-galactosidase from Thermotoga maritima. J Appl Microbiol. 2004;97:1006-14

\section{Submit your next manuscript to BioMed Central and we will help you at every step:}

- We accept pre-submission inquiries

- Our selector tool helps you to find the most relevant journal

- We provide round the clock customer support

- Convenient online submission

- Thorough peer review

- Inclusion in PubMed and all major indexing services

- Maximum visibility for your research

Submit your manuscript at www.biomedcentral com/submit 